\title{
Tennessee Williams's Dramatic World
}

\author{
Esmeralda Subashi, Ph.D \\ Miranda Ostrosi Veliaj, Ph.D. \\ University of Tirana \\ Faculty of Foreign Languages \\ English Language Department
}

E-mail: esmeraldasubashi@gmail.com

Abstract

\begin{abstract}
Tennessee Williams has been regarded as the greatest Southern dramatist and one of the most distinguished playwrights in the history of American drama. He is undoubtedly the most renowned American dramatist of the second half of the $20^{\text {th }}$ Century. This paper addresses and explores some of the main features of his dramatic works. His drama was a lyric or poetic one, and that is why the critic and scholar Frank Durham referred to him as "Tennessee Williams, theater poet in prose". When David Mamet describes William's plays as "the greatest dramatic poetry in the American language", he shares the widely accepted opinion that Williams brought to the language of the American theater a lyricism unequaled before or after. He infuses his dialogue with lyrical qualities so subtle that the reader or hearer, unaware, responds not to realistic speech but, instead, to speech heightened by such poetic effects as alliteration, rhythm, onomatopoeia, and assonance. As a Southern writer, Williams was attuned to the natural rhythm and melody of Southern speech, a melody, he says, heard especially in the voices of women. Characterization is one of Williams's strongest achievements as a dramatist. His people are imaginatively conceived yet so convincing that it is tempting to take them out of context and theorize about their lives before and after the action of the play. In place of realism, which stressed photographic duplication of the actual, a style that had dominated American stage for four decades, Williams insisted on a theater that was "plastic" that combined all the elements of productiondialogue, action, setting, lighting, even properties- in a unified, symbolic expression of a truth.
\end{abstract}

Keywords: a lyric/poetic drama, a Southern writer, characterization, plastic theater, controversial themes, symbols.

\section{Introduction}

Tennessee Williams, alongside Eugene O'Neill and Arthur Miller is regarded as one of the greatest American playwrights of the 20th century. He became a celebrity thanks to the favorable reception by both theater critics and spectators, and his fame and reputation could be undoubtedly attributed to Williams's two masterpieces- $A$ Streetcar Named Desire and The Glass Menagerie- as well as to a corpus of works including the Pulitzer Prize winner Cat on a Hot Tin Roof and more than 60 plays, among others The Rose Tattoo, Sweet Bird of Youth, Orpheus Descending, Suddenly Last Summer and Night of the Iguana.

Tennessee's younger brother, Daikin Williams was keen on predicting that two or three centuries later his older sibling would become more renowned than William Shakespeare (Kolin, 2008, p.3). In spite of the inflated fraternal praise, Tennessee Williams is unquestionably, the most influential American playwright after the II World War. Since the mid 1940s he convincingly entered the imagination of American audience and remained an authority figure in theater, film and popular culture as well. Lillian Hellman (Van Antwerp and Johns, 1984, p.255), his fellow American dramatist cast light on the reasons of this popularity:

With The Glass Menagerie of 1944 and A Streetcar Named Desire of 1947, he brought to the theater the greatest talent of the post-war generation. There are many good writers who do not influence men who came after them...influence is not the only measure of worth- but I think it safe to guess that Williams's influence on the theater will be there a hundred years from now because the mirror he held in his hand announced a new time, almost a new people, and the mirror will remain clear and clean. 
Actually, being a self-making writer, Williams projected himself into his plays. He disclosed his secrets in his works, just as the Bard did in his Sonnets. He desperately wanted and needed to be famous. This is why his entire life was spent in a continuous haze of premieres, parties, interviews, controversies and escapes into his subconscious. He was the fugitive dramatist trying hard to be accepted, but ironically enough, when he finally accomplished this, especially after $A$ Streetcar Named Desire won every major literary award, Williams turned into a self-critical and self-destructive human being. During his long career, Williams never managed to escape from despair and anxiety- the devils that tormented him all his life. Undoubtedly, he became the target of the most ferocious attacks ever recorded in the American theater and he remained as such until he died in 1983.

But what the critics pointed out as his biggest flaw was in reality the source of his strength. He was fueled by the inner world of his own madness and excesses - from his early masterpieces to his latest highly experimental plays. His art reflected the individuality, desire and sexuality of his characters- in a very open and bold way- in a way no other dramatist ever did before. This is why critic V. W. E. Bigsby (2000, p.64) rightly assumed that the underlying metaphors for Tennessee Williams's life and literary career were "the self as actor, society as a series of coercive fictions." His name and his plays became synonymous with desire, taboo, and the grotesque South.

\section{A lyric/poetic drama}

David Mamet (1983, p.124) described William's plays as "the greatest dramatic poetry in the American language", voicing the widely accepted opinion that Williams brought to the language of the American theater a lyricism radically different from that of other playwrights before or after. Tennessee Williams did not write "poetic plays" in the fashion of Maxwell Anderson, which were not as successful and appealing as the older dramatist had expected. On the contrary, Williams's plays are "dramatic poetry" as Mamet pointed out, being in line with the well-known critic, Frank Durham who referred to Tennessee Williams as the "Theater Poet in Prose". According to Durham (1971, p.4), "Eugene O'Neill was the first of the American playwrights to move thus beyond realism toward a new poetry of the theater, but today its chief figure is Tennessee Williams."

While T.S. Eliot thought that the poetic drama should be written in verse, his concept regarding the effect dramatic verse should produce coincided with how Williams used language in his plays. According to Eliot (1957, p.82), when confronted with of a poetic play, which he called verse drama, the spectators

expect poetry to be in rhythms which have lost touch with colloquial speech. What we have to do is to bring poetry into the world in which the audience lives and to which it returns when it leaves the theater; not to transport the audience into some imaginary world totally unlike its own, an unreal world into which poetry is tolerated. What I should hope might be achieved, by a generation of dramatists having the benefit of our experience, is that the audience should find, at the moment of awareness that it is hearing poetry, that it is saying to itself: "I could talk poetry too!" then we should not be transported into an artificial world; on the contrary, our own sordid, dreary daily world would be suddenly illuminated and transfigured.

This is exactly what Williams could achieve without using the risky artificial qualities of poetry. He raised the colloquial speech, very frequently the Southern colloquial speech, to the level of poetry, thanks to his sensitivity to verse's rhythms and patterns, its imagery and symbolism. And as Durham (1971, p. 11) highlighted it was "real speech, but real speech intensified and heightened, so that it not only evokes the pleasure of recognition but communicates the inexpressible, the very essence of character, emotion, and situation in a way traditionally associated with poetry."

Tennessee Williams imbued his dialogues with very subtle qualities and the reader or the hearer, subconsciously responds not the real speech but to a speech intensified by such poetic effects as alliteration, rhythm, onomatopoeia, and assonance.

\section{A Southern writer}

Williams's Southern origin is essential to the poetic qualities of his language, as many critics have pointed out. Williams is particularly noted for his long line, which achieves the most surprising effects through a repetition in the fashion of Gertrude Stein (Migid, 1964, p.282), by using archaic words, introducing unexpected "literary bookish words" and ironically elegant 
phrase turns, which brings about a stylized representation of the Southern diction, which is more conscious, more vague, but also much more imaginative than the Northern speech.

Being a Southern writer, Tennessee Williams was accustomed to and in full harmony with the natural rhythm and melody of Southern speech, which is heard particularly in the voices of women, as he himself pointed out. Stark Young (1945, p.505), a Southern critic, heard in The Glass Menagerie "behind the Southern speech in the mother's part... the echo of great literature, or at least respect for it."

Besides indiscernibly intensifying the dialogue of his characters, Williams uses their speech to emphasize their individual qualities. Amanda in The Glass Menagerie is too wordy, she never stops talking; Vee's dialogue in Orpheus Descending that symbolizes her sexual frustration is breathtaking; whereas Alma's obsession with the spiritual in the first part of Summer and Smoke is reflected in her ethereal speech about the Gulf Wind. Even the most illiterate characters created by Williams are as poetic in their speech as the most educated and cultivated ones. Thus, Stanley Kowalski, the "brutish" character in A Streetcar Named Desire has his unique rhythms, characterized by repetitions and inflections; Serafina in The Rose Tattoo manages to be very eloquent by using monosyllabic words only; Val in Orpheus Descending, talking about a little bird, gives a speech which at the same time is both lyric, heightened and being in line with his character, simple but accompanied by some kind of a strange sensation.

Williams's plays display the majority of the artistic features of the most renowned Southern writers of the modern era and anticipate the postmodern dilemma in a period which started with the integration and expansion of middle class, previously looked down. Almost in every play he wrote, Williams depicted the traditional themes, either elevated or satirized in the literary Works of Southern writers: agricultural versus urban society, Modern South versus Old South, aristocrats versus nouveau riche.

Placing emphasis on the irrational, the desperation of people in a universe where the cosmic laws do not work, as well as on the tragicomic analysis of conflicts between the aristocracy of Southern old values and the brutal force of Northern modern values, Williams's plays could be incorporated in the literary movement the critics call "Southern Gothic". He shares this area with other distinguished representatives of Southern Literature such as Flannery O'Connor, William Faulkner and Thomas Wolfe. Williams considered himself a member of the Southern school, which combined elements of expressionism, impressionism, surrealism, symbolism and naturalism in a special American mixture. The playwright himself stated that the South's frustration; oppression and poverty have made it the most natural and suitable place for the development of American Gothic (Tischler, 1961, p.25).

\section{Characterization}

Critics agree that characterization is one of the greatest achievements and strengths of Williams as a playwright (Griffin, 1995, p.19). His characters are products of a highly imaginative mind, but at the same time so convincing that one might be tempted to take them out of context and try to develop theories on their lives prior to and following the action of the play. Williams created great characters such as Amanda and Laura, Blanche and Stanley, Alma and John- memorable not only as individuals but also when they are contrasted to each other.

Williams created exceptional, larger than life female characters. They are beautiful, lively, imaginative but simultaneously so fragile and vulnerable as to properly deserve "The Moth Ladies of Tennessee Williams" label. This fragility and vulnerability is caused because sometimes they rely too much on the comfort of men around them, and when the latter in turn fail or ruin them, they ultimately turn to the kindness of strangers, seeking love, affection and compassion. This is what their creator, Tennessee Williams also longed for and sought almost all his life. It is a well-known fact that he identified himself more with his heroines, a fact proven by him stating that "I am Blanche DuBois!"

Williams's women characters live caught up between illusion and reality, sexuality and love. There are two categories of them: female characters who idealize reality and those who face it. The former escape to a world of dreams, such as Amanda in The Glass Menagerie or Blanche in A Streetcar Named Desire. They behave in a strange way because they cannot accept themselves or the others. The latter- Maggie in Cat on a Hot Tin Roof or Hannah in The Night of lguana occupy the first row in Williams's gallery of personages- they are dedicated to the time and place in which they live, and are full of life. Their desire to live might be selfish and related to love and sex. These realistic women characters feel real 
compassion for the others and are really sympathetic to them and their problems. Williams called himself an old-fashioned romantic. Based on his plays, by "romantic" he might have meant someone who believes in the power of love and the greatest love of all, as Williams showed through his plays is the affection and compassion you prove when you accept the reality.

Very often, the protagonist in Williams's plays is an alien, an outsider, a foreigner, an outcast, misunderstood and not trusted by the community such as Val Xavier in Orpheus Descending or Kilroy in Camino Real. Various critics have provided different perspectives on Williams's treatment of his characters and they have come up with several categories. Thus, the strangers appearing in Williams's plays are grouped into foreigners, saints and universal strangers (Wolter, 1995); the outcasts fall into sexual, religious and fugitive categories (Haley, 1999); and finally his female characters are regarded as being extremely alienated and estranged from men, themselves, other women and finally society (Walker, 2005).

Tennessee Williams said just before his death that his major aim was "to contribute an understanding about people". He tried to accomplish this through a more sympathetic characterization of the spiritual strangers, foreigners and outcasts.

\section{Plastic theater}

Instead of realism, which puts emphasis on the photographic representation of real life, a literary current that had dominated American stage for four decades, Tennessee Williams insisted on "plastic theater", combining all the production elementsdialogue, action, setting, and lighting, even costumes- in a unified and symbolic expression of the truth. This approach, no doubt revolutionary and avant-garde for the time, was outlined by the playwright himself in his introduction to The Glass Menagerie. Thus, in the "Production Notes" to this play, practically his most experimental one- where he discussed at length "extra-literary" elements such as music and lighting, Williams stated explicitly that he was seriously attempting to write a new kind of poetical drama. Labeling this product a "memory play", and this is why it should be staged "with unusual freedom of convention" he continued:

Because of its considerable delicate or tenuous material, atmospheric touches and subtleties of direction play a particularly important part. Expressionism and all other unconventional techniques in drama have only one valid aim, and that is a closer approach to truth. When a play employs unconventional techniques, it is not, or certainly shouldn't be, trying to escape its responsibility of dealing with reality, or interpreting experience, but is actually or should be attempting to find a closer approach, a more penetrating and vivid expression of things as they are. The straight realistic play with its genuine Frigidaire and authentic ice-cubes, its characters who speak exactly as its audience speaks, corresponds to the academic landscape and has the same virtue of a photographic likeness. Everyone should know nowadays the unimportance of the photographic in art: that truth, life, or reality is an organic thing which the poetic imagination can represent or suggest, in essence, only through transformation, through changing into other forms than those which were merely present in appearance. These remarks are not meant as a preface only to this particular play. They have to do with the conception of a new, plastic theater which must take the place of the exhausted theater of realistic conventions if the theater is to resume vitality as part of our culture (Williams, 1948, p.vi).

In this way Williams announced a new era in the American drama, characterized by a unique form, a popular artistic form that incorporated all levels of American culture and life and which was undoubtedly poetic in all its intentions. This search for an expressive concrete form, a form in harmony with the poetic vision became the leitmotiv that runs through all Williams's works.

The most essential elements of the plastic theater employed by Tennessee in The Glass Menagerie were: the use of a screen where themes, titles and pictures were shown to the audience at critical moments which represented an attempt to bold symbolism; the use of a recurring musical motive which becomes a leitmotiv; the use of cinematic techniques; the use of lighting that appears unreal to allow for the memory-based format of the play; as well as the use of an unrealistic set and set pieces in a symbolic way that the focus is not on realism but on the truth of the human emotions.

A review of the entire corpus of Williams's plays would reveal that his most significant contribution in terms of the idea of plastic theater was the conception of an American scenic language which was able to create dramatic forms with such powerful poetic qualities as to mesmerize the audience. Williams combined Southern speech, both musical and poetic, with colloquial speech and slang of the mid- $20^{\text {th }}$ century to create a lyrical dialogue style that held his signature. In his plays, 
Williams renounced from the traditional dramatic action to provide the spectators with an engaging insight into the emotionally complex lives of his personages.

\section{Themes}

Although each of Tennessee Williams's plays is unique, it is easy to find a connection between the themes they treat. William's major concern was no doubt the society's impact on the alien, the outcast, the foreigner, but this central theme of his works is closely related to love and romance, desire and sexuality, child-parent relationship and the predicament of the modern family, passing of time and fading of youth and beauty, isolation, guilt, loneliness, mendacity as well as illusion versus reality.

Another important contribution Williams brought to the American and world stage were the controversial themes that previously were considered taboo- his plays deal with the issues of human brutality and sexuality: madness, rape, incest, cannibalism, nymphomania, as well as extreme violent deaths- the majority of which are displayed in his masterpiece $A$ Streetcar Named Desire, such a shocking play that made the critics label it as "obscene" and "unacceptable" by the American morals. Williams commented a lot on the extreme violence of his plays, which he viewed as an inherent part of human nature; he was also aware, that the violence described in his plays was too particular for American life and mindset. As they did with the other great American playwright of the $20^{\text {th }}$ century- Edward Albee- the critics who pointed out the "excesses" in Williams's works, were just attacking his sexuality. When his plays were written, homosexuality was not an openly discussed subject, but the themes of desire and isolation they treat, show, among others the influence of growing up in a world that instills phobia against homosexuals.

According to Bigsby (2000), Williams's themes are universal and his favorite structure is that of a visit by his protagonist to the microcosm of the world itself. Their fears are common- the tyranny of time and death, which might be overcome only by love and procreation, the loss of youth and beauty, loneliness: "sentenced to solitary confinement in our own skins."

Characteristic of Williams's themes is that they are interwoven with and intensified by symbols. Thus, in $A$ Streetcar Named Desire, the streetcars named Desire and Cemetery symbolize the opposition and juxtaposition of desire and death. Other themes also build on contrasts: between responsibility and abandonment/escape in The Glass Menagerie, between flesh and spirit in Summer and Smoke, between mendacity and truth in Cat on a Hot Tin Roof, etc. Very often the theme is symbolized by an ordinary image expressed in the title, as it is the case with The Rose Tattoo.

\section{Conclusion}

Playwright, poet and prose writer Tennessee Williams has been very influential in American theater. His plays constitute a wonderful mixture of lyrical intensity, suffocating loneliness and hypnotizing violence. His highly emotional works deal with the endeavors of the sensitive protagonists to survive in a hostile world. He has been regarded as the greatest Southern playwright and one of the most distinguished dramatists in the history of American drama.

The fact that Williams's plays are as fresh and significant today as when they were first staged is a tribute to his genius about which he was truly modest. When the critics accussed him of having written about his own life, this is how Williams (1978, p.159) defended his approach: "It is the responsibility of the writer to put his experience as a being into work that refines it and elevates it and that makes of it an essence that a wide audience can somehow manage to feel in themselves: 'This is true."'

When Williams left this world in 1983, alone in a hotel room, abandoned by all his numerous former friends, dependent on the "kindness of strangers" (Williams, 1951, p.226), he left behind a priceless gift to the American and world-wide audience: his great plays- whose lyricism, humanity and theatrical impact enriched the achievements of the American theater and the hearts of its spectators. As Alice Griffin (1995, p.19) suggests, Williams's comment on Proust's Remembrance of Things Past might as well serve as his own epitaph, giving to the plays he wrote "his love, fear, loneliness, disgust, humor, and most important of all, his forgiving perception of the reasons for the tragicomedy of human confusion." (Williams, 1978, p.125) 


\section{References}

[1] Bigsby, C.W.E., (2000). Modern American Drama, 1945-2000. N.Y, Cambridge University Press.

[2] Bigsby, C.W.E., (1984). A Critical Introduction to Twentieth Century American Drama. Cambridge: Cambridge University Press.

[3] Durham, Frank. "Tennessee Williams, Theatre Poet in Prose", South Atlantic Bulletin, Vol. 36, No. 2, March 1971.

[4] Eliot, T.S., (1957). "Poetry and Drama", On Poetry and Poets. London: Faber and Faber.

[5] Griffin, Alice. (1995). Understanding Tennessee Williams. University of South Carolina Press.

[6] Haley, Darryl Erwin, (1999). Certain Moral Values: A Rhetoric of Outcasts in the Plays of Tennessee Williams. University of Alabama.

[7] Jackson, Esther Merle. (1977) "Tennessee Williams: 'The idea of a Plastic Form"” in Tennessee Williams: A Tribute, Ed. Jacque Tharpe. Jackson: University Press of Mississippi, 1977.

[8] Kolin, Philip C., Ed. (2008). The Influence of Tennessee Williams. Jefferson, North Carolina: McFarland\&Company, Inc., Publishers

[9] Kramer, Richard E., "The Sculptural Drama": Tennessee Williams's Plastic Theater"'Tennessee Williams Annual Review, No.5, 2002.

[10] Mamet, David. Rolling Stone, 14 April 1983.

[11] Migid, Marion. (1964). "The Innocence of Tennessee Williams". Essays in the Modern Drama, ed. Morris Freedman. Boston: D.C. Heath \& Co.

[12] Tischler, Nancy. (1961). Tennessee Williams: Rebellious Puritan. New York: Citadel Press.

[13] Van Antwerp, Margaret A., and Sally Johns. Ed. (1984). Tennessee Williams. Dictionary of Literary Biography. Documentary Series 41. Detroit: Gale.

[14] Walker, Kristine. (2005). The Alienation and Estrangement of the Female Characters in the Plays of Tennessee Williams. California State University Dominguez Hills.

[15] Williams, Tennessee. (1951) A Streetcar Named Desire. New York: Signet.

[16] Williams, Tennessee. (1948). The Glass Menagerie, A Play in Two Acts. Acting Edition. New York: Dramatists Play Service.

[17] Williams, Tennessee. (1978). Where I Live: Selected Essays, ed. Christine R. Day and Bob Woods. New York: New Directions.

[18] Wolter, Jurgen C.,"Strangers on Williams's Stage”, The Mississippi Quarterly, Vol. 49, 1995.

[19] Young, Stark. "The Glass Menagerie", New Republic 112, 16 April 1945. 